\title{
N-Bpin-Directed Borylation of (Hetero)Aryls
}

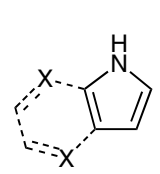

$\mathrm{X}=\mathrm{CH}, \mathrm{N}$

tmphen $=3,4,7,8$-tetramethyl-1,10-phenanthroline<smiles>Brc1c[nH]c2ccccc12</smiles>

$\gamma_{0}^{0}=p i n$<smiles>[R]c1cc(N)ccc1Br</smiles>
[\{lr(OMe)(cod) $\left.\}_{2}\right](0.25-2.5 \mathrm{~mol} \%)$ tmphen (1.0-5.0 mol\%) THF, $16 \mathrm{~h}, 80^{\circ} \mathrm{C}$ $\mathrm{R}^{1}$<smiles>Brc1c[nH]c2ccccc12</smiles><smiles>Brc1cc[nH]c1</smiles>

$57 \%$ yield<smiles>Nc1cc(Cl)c(Br)cc1Br</smiles>

$92 \%$ yield<smiles>N#Cc1cc(Br)c(N)cc1Cl</smiles>

$90 \%$ yield<smiles>[R]c1cc(N)c(Br)cc1[R]</smiles>

up to $93 \%$ yield<smiles>Brc1c[nH]c2cccnc12</smiles>

$83 \%$ yield<smiles>Nc1ccc(Br)cc1Br</smiles>

$88 \%$ yield

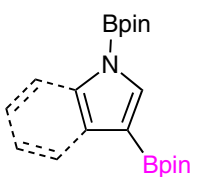

up to $91 \%$ yield

$\mathrm{R}^{1}=\mathrm{H}, \mathrm{F}, \mathrm{Cl}, \mathrm{Br}, \mathrm{OH}$ $\mathrm{OMe}_{2} \mathrm{CF}_{3}, \mathrm{CN}$

$\mathrm{R}^{2}=\mathrm{H}, \mathrm{Cl}, \mathrm{CF}_{3}, \mathrm{OMe}$, Bpin
Key words

borylation

catalysis

nitrogen

heterocycles

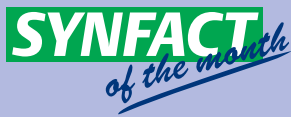

Significance: The authors report a regioselective pinacolatoboron (Bpin) functionalization of $\mathrm{C}-\mathrm{H}$ bonds of nitrogen heterocycles and anilines. Traceless Bpin installation does not require the in stallation and removal of a directing group. This methodology clearly opens a new route to complex unsaturated boronic esters.
Comment: For nitrogen heterocycles with less acidic $\mathrm{NH}$ groups, the addition of a tertiary amine is critical for successful borylation. For azaindoles, this preparation enables the formation of borylated heterocycles that are inaccessible with Bocdirected methods.

SYNFACTS Contributors: Paul Knochel, Thomas Klatt 